\title{
The Hexokinase Isoenzyme PII of Saccharomyces cerevisiae is a Protein Kinase
}

\author{
By P. HERRERO, R. FERNÁNDEZ AND F. MORENO* \\ Departamento de Biología Funcional, Area de Bioquimica y Biología Molecular, Facultad de \\ Medicina, Universidad de Oviedo, 33071-Oviedo, Spain
}

(Received 21 July 1988; revised 21 November 1988; accepted 14 December 1988)

The $H X K 2$ gene product has an important role in controlling carbon catabolite repression in Saccharomyces cerevisiae. We have raised specific antibodies against the hexokinase PII protein and have demonstrated that it is a $58 \mathrm{kDa}$ phosphoprotein with protein kinase activity. The predicted amino acid sequence of the $H X K 2$ gene product has significant homology to the conserved catalytic domain of mammalian and yeast protein kinases. Protein kinase activity was located in a different domain of the protein from the hexose-phosphorylating activity. The hexokinase PII protein level remained unchanged in P2T22D mutant cells ( $h x k 1 H X K 2$ glkl) growing in a complex medium with glucose. The protein kinase activity of hexokinase PII is regulated by the glucose concentration of the culture medium. Exit from the carbon catabolite repression phase and entry into the derepression phase may be controlled, in part, by modulation of the $58 \mathrm{kDa}$ protein kinase activity by changes in cyclic AMP concentration.

\section{INTRODUCTION}

Carbon catabolite repression, or glucose repression, is an important, global regulatory system in both prokaryotic and eukaryotic cells. Studies on the yeast Saccharomyces cerevisiae have indicated that the regulatory mechanisms affecting carbon catabolite repression in eukaryotes are different from those in bacteria. The evidence suggests that glucose repression does not appear to involve low levels of cAMP, a key metabolite in catabolite control of gene expression in Escherichia coli (Matsumoto et al., 1983; Eraso \& Gancedo, 1984).

To identify the different elements implicated in the mechanism of catabolite repression in yeast, a large number of mutants have been described (Entian, 1986; Gancedo \& Gancedo, 1986). Although the gene products and their biochemical functions are unknown in most cases, some biochemical knowledge exists from the study of snfl (Celenza \& Carlson, 1986) and hexl (Zimmermann \& Scheel, 1977) mutants.

The $S N F 1$ function is required for expression of glucose-repressible genes and the gene encodes a protein kinase (Celenza \& Carlson, 1986). The following genetic evidence suggests the $S S N 6$ gene product as a possible target of $S N F 1$ activity. The defect in $S U C 2$ expression in snf1 mutants can be suppressed by mutations at the SSN6 locus (Carlson et al., 1984). Both ssn6 mutants and $s n f 1$ double mutants show high-level, constitutive (glucose-insensitive) synthesis of secreted invertase. This suggests that $S S N 6$ is a negative regulator of $S U C 2$ and that $S N F 1$ prevents the repressive effect of SSN6 (Sarokin \& Carlson, 1984).

hexl mutants have a mutation in the structural gene for hexokinase PII (Entian \& Mecke, 1982) and are mainly affected in the repression of enzymes of disaccharide hydrolysis and the galactose pathway (Michels et al., 1983). The essential role of hexokinase PII in triggering glucose repression seems to be established (Fröhlich et al., 1984), but the molecular mechanism is unknown.

There is evidence that the proteolysis of hexokinase PII is not the triggering signal of carbon catabolite derepression in S. cerevisiae (Fernández et al., 1987). On the other hand, it has been 
suggested that xylose-induced phosphorylation of hexokinase PII in vivo may produce a change in the enzyme conformation which could provide the triggering signal to activate an additional activity (Fernández et al., 1986, 1987). Recently it has been reported that hexokinase PII can undergo autophosphorylation. The rate of autophosphorylation and the final extent of ${ }^{32} \mathrm{P}$ incorporation are stimulated by the presence of xylose in the assay mixture (Fernández et al., 1988). These results suggest that hexokinase PII could have a protein kinase activity which could catalyse the phosphorylation of an inactive derepressing signal to an active one. In this paper, we report that in addition to the hexose-phosphorylating activity, hexokinase PII also presents a protein kinase activity regulated by glucose and cAMP.

\section{METHODS}

Materials. These were all described recently (Fernández et al., 1988). In addition, $\left.{ }^{35} \mathrm{~S}\right] \mathrm{sulphate}$ (carrier free) was from New England Nuclear.

Strains and growth conditions. Saccharomyces cerevisiae G-517 (CECT 1317) was used as a wild-type strain. The mutant strains P2T22D (MAT $\alpha$ adel hxkl glkl), lacking hexokinase PI and glucokinase, and D.308.3 (MAT $\alpha$ $h x k l h x k 2$ glkl adel trpl his 2 met l4), lacking all three glucose-phosphorylating enzymes, were obtained from the Yeast Genetic Stock Center (University of California, Berkeley, USA). The mutant strain hexl (MAT $\alpha$ his4 adel hexl-18 MAL2-8C SUC3) was kindly provided by K.-D. Entian (University of Tübingen, FRG).

The cells were grown in flasks containing $300 \mathrm{ml}$ YPD medium [ $1 \%(\mathrm{w} / \mathrm{v})$ yeast extract, $2 \%(\mathrm{w} / \mathrm{v})$ peptone and $2 \%(\mathrm{w} / \mathrm{v})$ glucose] supplemented with $30 \mathrm{mg}$ adenine $\mathrm{l}^{-1}$, on a rotatory shaker at $28^{\circ} \mathrm{C}$. Strain D 308.3 was grown in flasks with $300 \mathrm{ml}$ medium containing $1 \%(\mathrm{w} / \mathrm{v})$ yeast extract, $2 \%(\mathrm{w} / \mathrm{v})$ peptone, $3 \%(\mathrm{v} / \mathrm{v})$ glycerol and $3 \%(\mathrm{v} / \mathrm{v})$ ethanol, supplemented with $30 \mathrm{mg}$ adenine $1^{-1}$, on a rotatory shaker at $28{ }^{\circ} \mathrm{C}$. Growth was followed by determination of the optical density at $600 \mathrm{~nm}$.

For labelling with $\left[{ }^{35}\right.$ S]sulphate, S. cerevisiae G-517 cells were grown to a density of $6 \times 10^{6} \mathrm{ml}^{-1}$ in YPD medium, collected by centrifugation, washed once in mineral medium (MM) (Kitazume et al., 1962) lacking inorganic sulphate, and resuspended at the same density in sulphate-free $M M$ with $2 \%(w / v)$ glucose as carbon source. After incubation at $30^{\circ} \mathrm{C}$ for $\left.20 \mathrm{~min},{ }^{35} \mathrm{~S}\right]$ sulphate was added to a concentration of $20 \mu \mathrm{Ci} \mathrm{ml}^{-1}\left(4 \times 10^{7}\right.$ d.p.m. $\mathrm{ml}^{-1}$ ), and the cells were labelled for $1 \mathrm{~h}$.

The cells were harvested from cultures, washed twice with distilled water and resuspended in the extraction buffer [10 mM-potassium phosphate, pH 7.0, 1 mM-EDTA. 4 mM-phenylmethylsulphonyl fluoride (PMSF) and $4 \mathrm{mM}$-sodium fluoride] for further treatment. PMSF and sodium fluoride were included as proteinase and phosphatase inhibitors respectively.

Purification of hexokinase PII. Hexokinase PII was purified to homogeneity, as described by Fernández et al. (1986), using a four-step procedure: cell-free extract preparation, hydroxyapatite chromatography, chromatofocusing and DEAE-Sephadex A-50 chromatography.

Preparation of antibodies. Antisera against homogeneously prepared hexokinase PII were raised by injecting New Zealand White rabbits with $0.1 \mathrm{mg}$ protein at one-week intervals as described by Fernández et al. (1987). Control sera were obtained from the same rabbits prior to the first injection of antigen and stored frozen at $-70{ }^{\circ} \mathrm{C}$. The titres of antisera were determined by Ouchterlony double diffusion analysis (Ouchterlony \& Nilsson, 1978) of serially diluted samples against purified enzyme. Maximal titre was attained about 5 weeks after the first injection.

Double diffusion analyses have demonstrated that hexokinase PII, hexokinase PI and glucokinase are not immunologically related. The hexokinase PI and glucokinase partially purified proteins did not react with the antiserum to hexokinase PII (Fernández et al., 1987).

Extraction of proteins, immunoprecipitation and Western blotting. Cells were collected by centrifugation and cellfree extracts prepared by vortexing in extraction buffer with glass beads (five times for $1 \mathrm{~min}$ with $1 \mathrm{~min}$ intervals of cooling in ice). Hexokinase PII was specifically immunoprecipitated from crude extracts with antiserum and protein A-Sepharose as described by Anderson \& Blobel (1983). Anti-hexokinase PII serum (25 $\mu$ l) was added to $200 \mu$ l of cell-free extract containing $0.6 \mathrm{mg}$ protein and then incubated at $4{ }^{\circ} \mathrm{C}$ for $60 \mathrm{~min}$. A suspension of protein A-Sepharose CL-4B ( $200 \mu \mathrm{l}, 5 \mathrm{mg}$ per tube) was added, and incubated with shaking at $4{ }^{\circ} \mathrm{C}$ for $30 \mathrm{~min}$. The Sepharose beads were pelleted by a 2 min centrifugation and the supernatant discarded. The beads were washed four times $(1 \mathrm{ml}$ per wash in $1 \%(\mathrm{v} / \mathrm{v})$ Triton X-100, $0 \cdot 1 \%(\mathrm{w} / \mathrm{v})$ SDS, $0 \cdot 5 \%(\mathrm{w} / \mathrm{v})$ sodium deoxycholate, $100 \mathrm{~mm}$ $\mathrm{NaCl}, 0.1 \%(\mathrm{w} / \mathrm{v})$ sodium azide, $10 \mathrm{~mm}$-potassium phosphate buffer, $\mathrm{pH} 7 \cdot 5$, with vortexing at each wash. Western blotting was performed as described previously (Fernández et al., 1987).

Analytical methods. Protein kinase activity of hexokinase PII was determined using immune complexes or purified hexokinase PII as sources of enzyme. Immune complexes were washed twice with assay buffer $(40 \mathrm{~mm}$ HEPES/ $\mathrm{NaOH}, \mathrm{pH} 7 \cdot 4,10 \mathrm{~mm}-\mathrm{MgCl}_{2}, 0.5 \mathrm{~mm}$-DTT). The protein A-Sepharose beads were then resuspended in assay buffer $(40 \mu \mathrm{l})$ containing $20 \mu \mathrm{m}-\mathrm{ATP}$, casein or histone $\left(1 \mathrm{mg} \mathrm{ml}^{-1}\right)$, and $3 \mu \mathrm{Ci}$ of $\left[\gamma^{-32} \mathrm{P}\right] \mathrm{ATP}\left(6 \times 10^{6}\right.$ 
d.p.m.) and incubated at $30^{\circ} \mathrm{C}$ for $15 \mathrm{~min}$. The reaction was terminated and sodium dodecyl sulphate polyacrylamide gel electrophoresis (SDS-PAGE) gels were run and analysed as described previously (Fernández et al., 1988). Glucose-phosphorylating activity of hexokinase PII was assayed as previously described (Fernández et al., 1985).

Glucose was determined by a glucose oxidase-peroxidase coupled assay. Protein was determined by the Lowry method with bovine serum albumin as standard.

\section{RESULTS AND DISCUSSION}

\section{Immunological and biochemical evidence for the identification of the hexokinase PII as a protein kinase}

Immunoprecipitation from $\left[{ }^{35}\right.$ S $]$ sulphate-labelled $S$. cerevisiae protein extracts followed by gel electrophoresis showed a single radioactive band in the immune complex, with an apparent molecular mass of $58 \mathrm{kDa}$ (data not shown). This band was not present when preimmune serum was used for immunoprecipitation or when the antibody was preincubated with a slight excess of unlabelled enzyme prior to addition to the labelled crude extract. This suggests that the antibodies elicited in the rabbit by immunization with pure hexokinase PII were specific for the enzyme.

To establish whether hexokinase PII has protein kinase activity immune complexes containing the $58 \mathrm{kDa}$ protein were prepared and transfer of phosphate from $\left[\gamma^{32} \mathrm{P}\right] \mathrm{ATP}$ to either caseins or histone was assayed. Protein kinase activity was present in the immune complexes (Fig. 1, lanes 1-3). This activity was absent when preimmune serum was used (Fig. 1, lane 6), suggesting that the $58 \mathrm{kDa}$ protein has protein kinase activity.

Previous work in our laboratory showed that a single protein band with an apparent molecular mass of $58 \mathrm{kDa}$, which corresponded to hexokinase PII, was obtained by using a four-step purification procedure followed by gel electrophoresis (Fernández et al., 1986). A protein kinase activity was present in the purified hexokinase PII preparation (Fig. 1, lanes 4-5).

We have demonstrated that immune complexes prepared using antisera raised against purified hexokinase PII from $S$. cerevisiae contain a protein kinase activity that is able to transfer phosphate from $\left[\gamma^{-32} \mathrm{P}\right] \mathrm{ATP}$ to histone III-S, $\alpha$-casein or $\beta$-casein. The simplest interpretation of these data is that the hexokinase PII $(58 \mathrm{kDa})$ is a protein kinase, although we cannot formally eliminate the possibility that the $58 \mathrm{kDa}$ protein coprecipitates with a protein kinase. The interpretation that hexokinase PII is itself a protein kinase is, however, supported by the observation that the purified hexokinase PII also has protein kinase activity. This interpretation is also supported by the fact that hexokinase PII is autophosphorylated and that the mechanism of hexokinase PII autophosphorylation is intramolecular in nature (Fernández et al., 1988).

\section{Sequence homology between hexokinase PII and several protein kinases}

To gain insight into the possible function as protein kinase of the $H X K 2$ gene product, we compared the predicted amino acid sequence of hexokinase PII (Fröhlich et al., 1985; Stachelek et al., 1986) with the sequences of three serine/threonine protein kinases and two tyrosine protein kinases. In all cases, a cluster of glycines within the sequence Gly-X-Gly-X-X-Gly lies 15-28 residues to the amino terminal side of the lysine implicated in binding ATP (Kamps et al., 1984 ; Bennett \& Kennedy, 1987). Within the hexokinase PII sequence, Lys-252 is in a position that corresponds to the ATP-binding residue in other protein kinases; the sequence Gly-X-Gly$\mathrm{X}$-X-Gly begins at residue 232 (Fig. 2). We can conclude that the deduced amino acid sequence of hexokinase PII contains a region of high homology to a number of other protein kinases (Fig. 2). Amino acid sequences outside the putative catalytic domain are not homologous among the various protein kinases and are probably important for functions that are specific to particular kinases (Parker et al., 1986; Knopf et al., 1986). 


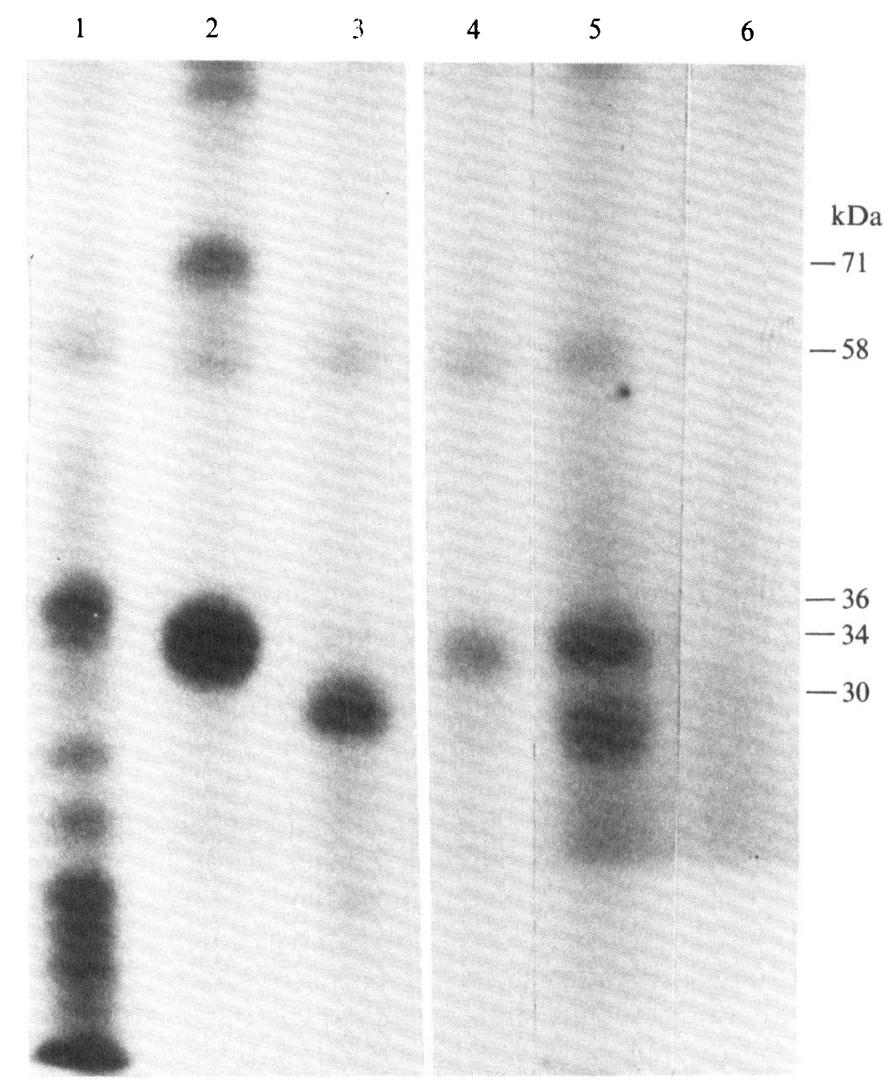

Fig. 1. Protein kinase activity of hexokinase PII. Immunoprecipitates containing a $58 \mathrm{kDa}$ protein were prepared from proteins extracted from wild-type cells and assayed for their ability to transfer [32P]phosphate from $\left[\gamma^{32} \mathrm{P}\right]$ ATP to the following proteins: histone III-S (lane 1); $\alpha$-casein (lane 2); $\beta$-casein (lane 3). Hexokinase PII purified to homogeneity was assayed for its ability to transfer $\left.{ }^{32} \mathrm{P}\right]$ phosphate from $\left[\gamma^{-32} \mathrm{P}\right]$ ATP to $\alpha$-casein (lane 4) or whole casein (lane 5). Lane 6 shows the absence of $\alpha$-casein phosphorylation by an immunoprecipitate obtained with preimmune serum. After $15 \mathrm{~min}$ incubation at $30^{\circ} \mathrm{C}$, the products of the reaction were analysed by SDS-PAGE. After staining, the gel was dried and fluorographed for $2 \mathrm{~d}$ at $-70^{\circ} \mathrm{C}$ using X-ray film.

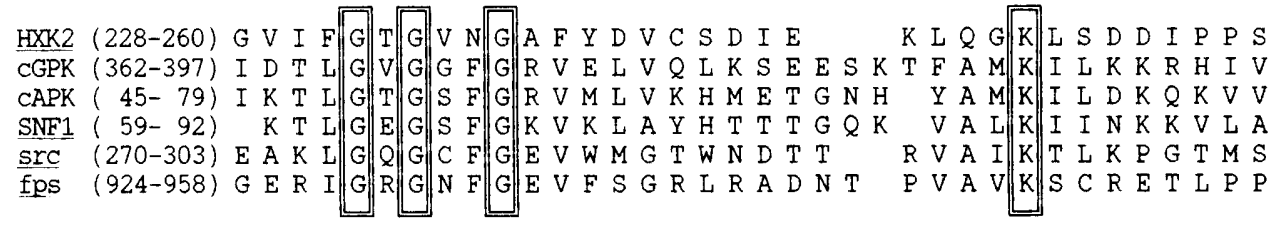

Fig. 2. Related amino acid sequences of protein kinases. Alignment of amino acid sequences surrounding the ATP-binding region of three serine/threonine protein kinases - cGMP-dependent protein kinase (cGPK), cAMP-dependent protein kinase (cAPK), yeast $S N F 1$ gene product (Hunter \& Cooper, 1985; Celenza \& Carlson, 1986) - and two tyrosine protein kinases - pp60 $0^{v-s r c}$ (src), P140"ag-fps ( fps) (Hunter \& Cooper, 1985) with the hexokinase PII (HXK2). Amino acids homologous to lysine 252 and the Gly-X-Gly-X-X-Gly sequence of hexokinase PII are boxed. Amino acid abbreviations: A, Ala; C, Cys, D, Asp; E, Glu; F, Phe; G, Gly; H, His; I, Ile; K, Lys; L, Leu; M, Met; N, Asn; P, Pro; Q, Gln; R, Arg; S, Ser; T, Thr, V, Val; W, Trp; Y, Tyr. 


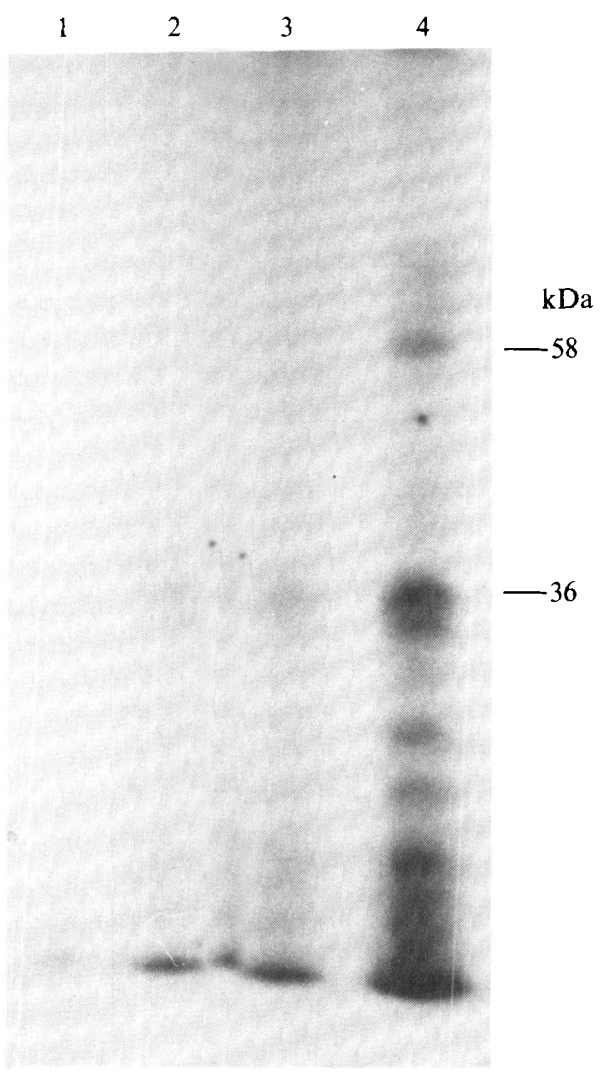

Fig. 3

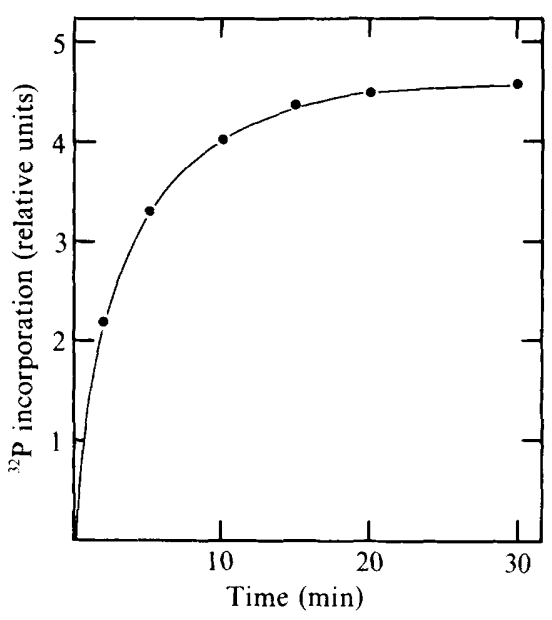

Fig. 4

Fig. 3. Protein kinase activity of hexokinase PII extracted from several yeast mutant strains. Immunoprecipitates containing a $58 \mathrm{kDa}$ protein were prepared. After extensive washing, they were assayed for their ability to transfer $\left[{ }^{32} \mathrm{P}\right]$ phosphate from $\left[\gamma^{32} \mathrm{P}\right] \mathrm{ATP}$ to histone III-S. The reaction products were analysed by SDS-PAGE. After staining, the gel was dried and fluorographed for $2 \mathrm{~d}$ at $-70^{\circ} \mathrm{C}$ using X-ray film. Lanes 1 and 4 , immunoprecipitates obtained from the wild-type strain G-517 (with preimmune serum in lane 1 ); 2 , immunoprecipitate obtained from mutant hexl; lane 3 , immunoprecipitate obtained from mutant D.308.3.

Fig. 4. Phosphorylation of histone by hexokinase PII. Immunopurified hexokinase PII from the wildtype strain G-517 was used to assay phosphate transfer from $\left[\gamma-{ }^{32}\right.$ P]ATP to histone III-S. At different times the reaction products were analysed by SDS-PAGE and autoradiography. The radioactive protein band of $36 \mathrm{kDa}$ was quantified by integrating the area of the peak obtained by scanning for absorbance at $558 \mathrm{~nm}$. Typical results are shown.

\section{Hexokinase-PII-dependent protein kinase activity in different mutant strains}

To confirm that the kinase activity in the immune complex was associated with the hexokinase PII protein, two mutant strains were examined to check if mutations in the hexokinase PII structural gene could also affect the protein kinase activity.

Immunoprecipitates were prepared from the wild-type strain G-517 and the mutant strains hexl and D. 308.3 ( $h x k l h x k 2$ glkl). The cells were harvested when the glucose concentration reached $70 \%$ of the original value. The $58 \mathrm{kDa}$ protein kinase from the wild-type strain (Fig. 3, lane 4) catalysed phosphate transfer from $\left[\gamma^{32} \mathrm{P}\right]$ ATP to histone III-S. This activity was absent 
when the immunoprecipitation reaction was performed with preimmune serum (Fig. 3, lane 1). The $58 \mathrm{kDa}$ phosphoprotein corresponds to hexokinase PII which was autophosphorylated during the reaction (Fernández et al., 1988). The protein kinase extracted by immunoprecipitation from hexl (lane 2) and D.308.3 (lane 3) was almost undetectable. This experiment demonstrated that the protein kinase activity in immune complexes prepared from the wild-type strain, using antibody against hexokinase PII, was severely impaired in the hex 1 mutant, with less than $4 \%$ of the wild-type activity, and was decreased in the triple mutant D.308.3 ( $h x k 1$ $h x k 2 \mathrm{glkl}$ ) to $10 \%$ of the wild-type activity. Western blotting of the proteins in the immune complexes showed that approximately equal amounts of $58 \mathrm{kDa}$ protein were precipitated from the cells of the strains tested (data not shown). Combining the present data, we suggest that the $58 \mathrm{kDa}$ immunoprecipitated protein kinase activity was associated with the $H X K 2$ gene product.

This result also suggests that hexokinase PII is a protein kinase whose activity is located in a different domain of the protein from the hexose-phosphorylating activity. In mutants hex 1 and D. 308.3 the structural gene of hexokinase PII carried two different mutations and the residual protein kinase activity was different. These results indicate that hexokinase PII is a bifunctional enzyme having a hexose-phosphorylating and a protein kinase activity. These two activities could be located in different domains of the protein and, therefore, be affected to a different extent by the two mutations. The existence of two domains in the hexokinase PII protein was demonstrated previously by results obtained with hexokinase PII structural gene mutants hex $I^{\mathrm{r}}$. The hex $l^{\mathrm{r}}$ mutation caused defects in carbon catabolite repression, but did not affect normal hexose-phosphorylating activity (Entian \& Fröhlich, 1984).

\section{Time course of protein (histone III-S) phosphorylation by immunoprecipitated hexokinase PII}

S. cerevisiae G-517 was harvested at an $\mathrm{OD}_{600}$ of 0.9 , when the glucose concentration had reached $70 \%$ of the original value. The $58 \mathrm{kDa}$ protein kinase activity extracted by immunoprecipitation was used to assay phosphate transfer from $\left[\gamma-{ }^{32} \mathrm{P}\right] \mathrm{ATP}$ to histone III-S (Fig. 4). Within 2 min, phosphorylation of histone III-S reached $50 \%$ of the maximum. Maximal phosphorylation was reached after about $15 \mathrm{~min}$.

\section{Changes in protein kinase and hexose-phosphorylating specific activities of hexokinase PII during cell growth}

The level of protein kinase activity of hexokinase PII in yeast cultures growing under different nutritional conditions is a subject of interest. Hexokinase PII was immunopurified from cultures of mutant P2T22D as described in Methods. Hexokinase PII immunopurified from fermentative yeast cultures ( $28 \mathrm{~mm}$-glucose), showed a high histone-phosphorylating specific activity (Fig. 5). Hexokinase PII from cultures growing on $1 \mathrm{~mm}$-glucose showed $30 \%$ of maximum histone-phosphorylating specific activity. The glucose-phosphorylating specific activity remained constant during the time of the experiment. The level of $58 \mathrm{kDa}$ protein per cell, as detected by Western blotting analysis, did not change significantly. These results indicate that the protein kinase activity of the hexokinase PII is regulated by the glucose level in the culture. The specific activity of protein kinase decreased when the predominant metabolic conditions were gluconeogenic and carbon catabolite repression was relieved.

\section{Effect of cAMP and other nucleotides on the protein kinase activity of hexokinase PII}

The protein kinase activity of hexokinase PII was stimulated in vitro by physiological concentrations of cAMP : 1 .25 $\mu$ M-cAMP elicited a 3.5-fold stimulation (Fig. 6). A similar extent of stimulation was also observed with $2 \mu \mathrm{M}$-dibutyryl cAMP but not with the same concentration of dibutyryl cGMP, GDP, GTP or AMP (data not shown). François et al. (1984) showed that addition of glucose to a suspension of $S$. cerevisiae caused a transient increase in the concentration of cAMP; thus the effect of glucose level on the protein kinase activity of hexokinase PII could be mediated by the intracellular cAMP concentration. 


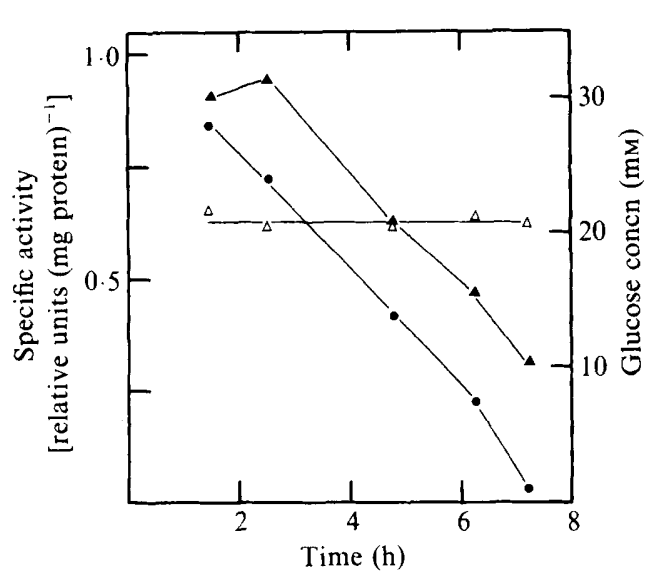

Fig. 5

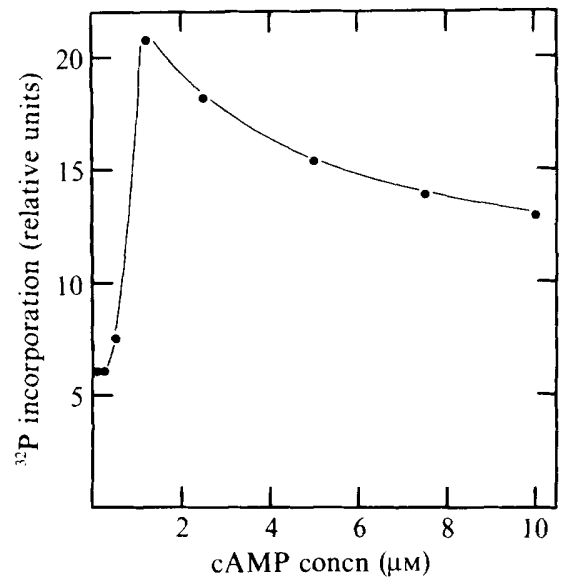

Fig. 6

Fig. 5. Effect of different nutritional conditions on the protein kinase activity of hexokinase PII. The mutant strain P2T22D was grown as indicated in Methods and the cells were harvested at different times. Glucose concentration was determined in the supernatant (O). After washing with distilled water the cells were resuspended in extraction buffer, extracts were prepared as indicated in Methods, and glucose-phosphorylating activity was determined in the extracts $(\triangle)$. Immunoprecipitates containing the $58 \mathrm{kDa}$ protein were also prepared and assayed for their ability to transfer $\left[{ }^{32} \mathrm{P}\right]$ phosphate from $\left[\gamma^{32} \mathrm{P}\right] \mathrm{ATP}$ to histone III-S $(\boldsymbol{\Delta})$. The reaction products were analysed by SDSPAGE and autoradiography. The radioactive protein band of $36 \mathrm{kDa}$ was quantified as indicated in the legend to Fig. 4. Typical results are shown.

Fig. 6. Dependence of protein kinase activity of hexokinase PII on the concentration of cAMP. The wild-type strain G-517 was grown as indicated in Methods and the cells were harvested at an $\mathrm{OD}_{600}$ of 0.9 , when the glucose concentration had reached $70 \%$ of the original value. The protein kinase activity of the $58 \mathrm{kDa}$ protein prepared by immunoprecipitation was assayed in the presence of the indicated concentrations of cAMP. Typical results are shown.

The authors thank Professor S. Gascón for his interest in this work and Dr C. L. Otin for many interesting suggestions. This work was supported by grants from the Comisión Asesora de Investigación Cientifica y Técnica (PB870191) and from the Fondo de Investigaciones Sanitarias de la Seguridad Social.

\section{REFERENCES}

Anderson, D. J. \& Blobel, G. (1983). Immunoprecipitation of proteins from cell-free translations. Methods of Enzymology 96, 111-120.

BennetT, M. K. \& Kennedy, M. B. (1987). Deduced primary structure of the $\beta$ subunit of brain type II $\mathrm{Ca}^{2+} /$ calmodulin-dependent protein kinase determined by molecular cloning. Proceedings of the National Academy of Sciences of the United States of America 84, 1794-1798.

Carlson, M., Osmond, B. C., Neigeborn, L. \& BONSTEIN, D. (1984). A suppressor of snfl mutations causes constitutive high-level invertase synthesis in yeast. Genetics 107, 19-32.

Celenza, J. L. \& Carlson, M. (1986). A yeast gene that is essential for release from glucose repression encodes a protein kinase. Science 233, 1175-1180.

ENTIAN, K.-D. (1986). Glucose repression: a complex regulatory system in yeast. Microbiological Sciences 3 , 366-371.
Entian, K.-D. \& Frohlich, K. U. (1984). Saccharomyces cerevisiae mutants provide evidence of hexokinase PII as a bifunctional enzyme with catalytic and regulatory domains for triggering carbon catabolite repression. Journal of Bacteriology 158, 29-35.

Entian, K.-D. \& Mecke, D. (1982). Genetic evidence for a role of hexokinase isoenzyme PII in carbon catabolite repression in Saccharomyces cerevisiae. Journal of Biological Chemistry 257, 870-874.

Eraso, P. \& Gancedo, J. M. (1984). Catabolite repression in yeast is not associated with low levels of cAMP. European Journal of Biochemistry 141. 195198.

Fernández, R., Herrero, P. \& Moreno, F. (1985). Inhibition and inactivation of glucose-phosphorylating enzymes from Saccharomyces cerevisiae by Dxylose. Journal of General Microbiology 131, 27052709. 
Fernández, R., Herrero, P., Fernández, M. T. \& MORENO, F. (1986). Mechanism of inactivation of hexokinase PII of Saccharomyces cerevisiae by Dxylose. Journal of General Microbiology 132, $3467-$ 3472.

Fernández, T., Herrero, P., Lopez-Boado, Y. S., Fernández, R. \& Moreno, F. (1987). Proteolysis of hexokinase PII is not the triggering signal of carbon catabolite derepression in Saccharomyces cerevisiae. Journal of General Microbiology 133, 2509-25I6.

Fernández, R., HERrero, P., FERnÁNDEZ E., FERNÁNDEZ, M. T., LOPEZ-BOADO, Y. S. \& MORENO, F. (1988). Autophosphorylation of yeast hexokinase PII. Journal of General Microbiology 134, 24932498.

François, J., Van Schaftingen, E. \& Hers, H.-G. (1984). The mechanism by which glucose increases fructose 2,6-bisphosphate concentration in Saccharomyces cerevisiae. A cyclic-AMP-dependent activation of phosphofructokinase 2. European Journal of Biochemistry 145, 187-193.

Fröhlich, K. U., ENTIAN, K. D. \& MECKE, D. (1984). Cloning and restriction analysis of the hexokinase PII gene of the yeast Saccharomyces cerevisiae. Molecular and General Genetics 194, 144-148.

Fröhlich, K. U., Entian, K. D. \& Mecke, D. (1985). The primary structure of the yeast hexokinase PII gene $(H X K 2)$ which is responsible for glucose repression. Gene 36, 105-111.

GANCEDO, J. M. \& GANCEDO, C. (1986). Catabolite repression mutants of yeast. FEMS Microbiology Letters 32, 179-187.

Hunter, T. \& COOPER, J. A. (1985). Protein-tyrosine kinases. Annual Review of Biochemistry 54, 897930.

Kamps, M. P., Taylor, S. S. \& Sefton, B. M. (1986). Direct evidence that oncogenic tyrosine kinases and cyclic AMP-dependent protein kinase have homologous ATP-binding sites. Nature, London 310, 589592.
Kitazume, Y., Ycas, M. \& Vincent, W. S. (1962). Metabolic properties of a ribonucleic acid fraction in yeast. Proceedings of the National Academy of Sciences of the United States of America 48, 265-269.

Knopf, J. L., LeE, M., Sultzman, L. A., KRIZ, R. W., LOOMIS, C. R., HewICK, R. M. \& BELL, R. M. (1986). Cloning and expression of multiple protein kinase C cDNAs. Cell 46, 491-502.

Matsumoto, K., Uno, I., Ishikawa, T. \& Oshima, Y. (1983). Cyclic AMP may not be involved in catabolite repression in Saccharomyces cerevisiae: evidence from mutants unable to synthesize it. Journal of Bacteriology 158, 898-900.

Michels, C. A., Halmenberger, K. M. \& Silvestre, Y. (1983). Pleiotropic mutations regulating resistence to glucose repression in Saccharomyces cerevisiae are allelic to the structural gene for hexokinase B. Journal of Bacteriology 153, 574-578.

OUCHTERLONY, O. \& NilsSON, L. A. (1978). Handbook of Experimental Immunology, 3rd edn, pp. 1-19. Edited by D. H. Weir, Oxford: Blackwell Scientific Publications.

Parker, P. J., Coussens, L., Totty, N., Rhee, L., Young, S., Chen, E., Stabel, S., Waterfield, M. D. \& UlLRICH, A. (1986). The complete primary structure of protein kinase $\mathrm{C}$ - the major phorbol ester receptor. Science 233, 853-859.

SAROKIN, L. \& Carlson, M. (1984). Upstream region required for regulated expression of the glucoserepressible $S U C 2$ gene of Saccharomyces cerevisiae. Molecular and Cellular Biology 4, 2750-2757.

Stachelek, C., Stachelek, J., Swan, J., Bostein, D. \& KonigsBerG, W. (1986). Identification, cloning and sequence determination of the genes specifying hexokinase A and B from yeast. Nucleic Acid Research 14, 945-963.

ZimmermanN, F. K. \& Scheel, I. (1977). Mutants of Saccharomyces cerevisiae resistant to carbon catabolite repression. Molecular and General Genetics 154, 75-82. 